\title{
An Italian Business Model for Engaging Organisations to Social Wellness: A Focus on the for Benefit Companies
}

\author{
Maria Antonella Ferri ${ }^{1} \&$ Maria Palazzo ${ }^{2}$ \\ ${ }^{1}$ Universitas Mercatorum, Italy \\ ${ }^{2}$ Università degli Studi di Salerno, Italy \\ Correspodence: Maria Palazzo, Università degli Studi di Salerno, Italy. E-mail: mpalazzo@unisa.it
}

Received: July 27, 2018

Accepted: September 26, 2018

Online Published: October 12, 2018

doi:10.5539/ijbm.v13n11p142

URL: https://doi.org/10.5539/ijbm.v13n11p142

\begin{abstract}
In 2015, a new kind of company was introduced by law in Italy: the forBenefit Company (fBComp). Such kind of firms is characterized by a relevant novelty: they are for-profit companies whose statute explicitly recognizes the impact of managerial decisions on the wellness of society as well as on shareholders. This study focuses on fBComps as organizations which bases their survival on social legitimacy. Such public recognition can be achieved through creating relationships with social and economic actors (Golinelli, 2010). The objective of the current paper is to open up to a scientific and methodological discussion about the contribution that the social behavior of a company can give to its sustainable survival in light of the logic of diffused value co-creation. The study analyzes the fBComp as a new "social" business model (SBM), which evolves and goes far beyond the Corporate Social Responsibility (CSR) phenomenon. This topic posits some main research questions: is that a new form and method for value-production and distribution? How does it affect existent corporate governance logics? Results illustrate how this business model operates in practice, or, in other words, the practical applications for the concept of business for-benefit (Rawhouser, Cummings, \& Crane, 2015). By conducting a desk analysis, based on a content analysis, using the results of the first Italian Report on fBComp, the contribution draws a portrait of this business model's main features and explains how or if it impacts management practices, shareholders and other kind of stakeholders.
\end{abstract}

Keywords: forBenefit, social legitimacy, isomorphism, consonance, social value co-creation, sustainability, stakeholders

\section{Introduction}

During the twentieth century, for-profit corporations have been considered a kind of legal, static creation of laws, sustained by jurisprudence.

Recently, however, the distinction between for-profits and non-profits is not anymore so clear.

During the financial crisis, organizations have been attacked for their unfair relationship to the whole society (Hiller, 2013). For this reason, some entrepreneurs, managers and governments have become more open to rethinking the traditional corporation (Murray, 2012).

From this openness has sprung an impassioned social enterprise movement and within the social enterprise world, we focus primarily on the benefit corporation model.

Specifically, we argue that for-profit companies nowadays work along a scale of conducts in which they disregard, accept, or embrace social goals. And, in the same way, also "non profits firms" have assumed some tools of for-profits in support of their social aims.

Thus, it follows hybrid forms of organizations that have blurred the lines between private sector and social orientation.

The most noticeable of the hybrid units are For Benefit Corporation o For Benefit Company, whose chase of profit is secondary to, or comparable with, their gain to generate a public value.

This organizational diversity proposes that forms of organization need to be considered not as receptacles of assets but as legal signs that drive the strategic conduct of markets. 
In other words, for long time, the operative assumption motivating entity formation was maximizing shareholder value: it was expected that investors and firms wanted to maximize profits excluding other objectives.

But what does "maximizing shareholder value" mean? This question has been at the heart of literature debate for decades. This concept has produced numerous corporate theories and models, but no simple answers.

Lately, nevertheless, concepts as sustainable, business ethics, citizenship - that were proposed for nonprofits companies - have become a part of the for-profit entities (Wilburn and Wilburn, 2014).

In some parts of the world, new hybrid forms of companies are emerging, referred to as Benefit Corporations that are obliged to reach public benefit in addition to give profits to shareholders (Hiller, 2013). According the point of view of American Bar Association's, the benefit corporation is an "entity model" that does not maximize shareholder value, but sacrifices some of that value in favor of alternate goals (Hasler, 2014).

The legal status of Benefit Corporation has been approved in five states in the US and is being considered in many others.

Italy is one of the first country outside the US to pass benefit corporation legislation and to introduce the for Benefit Company (Law 28 December 2015, no. 208, art. 1, para 376-382).

We can thus ask: does a shift in paradigm is occurring from profit vs. non-profit to recognition of a new way? Do the companies become more desirable from the perspective of all stakeholders and thus maintain their shareholder supremacy with a plus?

\subsection{Difference between US and Italian Context}

In this scenario, B Lab, a non-profit company created in the USA, provided tools essential for putting together profit and social advantage. They shaped a Social Impact Assessment performance program to develop a Certified B Corporation which also serves as an assessment tool for benefit corporations.

According to Hiller (2013 p. 299), the Benefit Corporation is "an innovative and new legal form of business that modifies the profit maximization and shareholder primacy corporate law paradigm".

In this regard, this form raises a lot of debates: i) the relationship between Benefit Corporation and CSR (Brammer, Jackson, Matten, 2012). The aim of Benefit Corporation is to generate a form that mandates non-profit maximizing behavior (Loewenstein, 2013). For this reason, it could be not in contrast with CSR or other forms of societal interest, because it is regarded as a dynamic searching for balance; ii) the relationship between corporate governance and legal aspects: board composition and relationship between majority and minority shareholders. Some authors are wondering what effect Benefit Corporation would have on corporate governance (Hiller, 2013). In the USA context, a significant novelty in the Model Legislation is the necessity that a benefit corporation has a benefit director, who has to be independent of the organization (Loewenstein, 2013 p. 1024). In Italian context, this particular director is not recognized. It follows that, in any case, the responsible does not have an easy task due to the fact that he/she has to assess every choice made by the directors to determine whether the decision is in line with the aim of benefit corporation (Loewenstein, 2013). In the contrary case, there will be a liability of directors. Now, having an independent directors on the board, as in USA context, reviewing every decision, may be problematic but also an opportunity. This issue is fit in the various dimensions that are observed in order to obtain certification, because of the governance dimension has the lowest weight in Italy (Venturi, Rago, 2016).

In our opinion the Corporate Governance values are important for the definition of social organization and the structure, which depends the action of board; iii) the discussion on the forms and procedures of production of value. The Shared Value approach (Porter and Kramer 2011) says that companies need to achieve not only profit but also societal benefits (Hiller, 2013). In this way, an organization affects and is affected by social challenges; iv) social impact communication strategies. In recent years, tools for social impact measurement are developing (Stubbs, 2014). This includes the B-impact assessment, a tool established by B-Lab, which issues the B Corp certification. B Corps, in a normative view, could be future likely Benefit Corporations. In this perspective, academics emphasized the significance for this corporation to assess their social impact and promote their performance to stakeholders (Rawhouser, Cummings and Crane, 2015).

In light of the above considerations, we questioned ourselves whether the fBComp represents a new kind of 
business model for the Italian scenario or not.

The goal of this research is to consider the Benefit Corporation in the Italian scenario as an adequate way to develop CSR at company's level.

The paper also contributes to business management area by stimulating new researches on the topic. For the remainder, the structure of the paper is: after reviewing the literature on the theme, we conduct and discuss a desk analysis, developing a content analysis, on Italian firms. Finally, we present our conclusions.

\section{For Benefit Company as a Different Business Model?}

The research questions that drives this study is "Can a for-benefit firm be considered as the new business model in terms of social sustainability?" To find an answer, we have decided to investigate the concept of business model itself, as well as the usefulness of models. We draw insight from fields other than management. Over time, an indefinite number of philosophers have investigated how such models are applied.

The concept of business model has become accepted in board rooms, by managers in companies, etc.

Actually, it is more used currently than almost any other notion in strategy. The ubiquity of the term proposes that business models are significant to the world of academics. Public awareness of its practicality seems to fly against the academic unwillingness to acknowledge the term.

One role of business models is to deliver a set of common level descriptors of how a company manages itself to generate value in a lucrative way.

This description is evident in many ways and forms, and Table 1 presents $\mathrm{s}$ a few examples.

Table 1. Business model approach

\begin{tabular}{|c|c|c|}
\hline Authors & Definition & Focus of analysis \\
\hline \multirow[t]{5}{*}{ Teece } & \multirow[t]{5}{*}{ How a company gives value to consumers } & Situates the business model concept. \\
\hline & & Considers business model innovation as technical \\
\hline & & innovation. \\
\hline & & Examples: Netflix on line DVD rental; Sea Land \\
\hline & & Container \\
\hline \multirow[t]{3}{*}{ Zott, Amit } & A system of interdependencies actions that & Emphasizes interdependencies beyond firm boundaries. \\
\hline & transcends the focal company & Good design needs: Content, Structure and Governance. \\
\hline & & Example: Zara \\
\hline \multirow[t]{3}{*}{ Williamson } & ...cost innovation business model offers advantages & How low cost business models from China (and India) \\
\hline & in radically new ways meaning more for less. & work. \\
\hline & & Examples: Nano car- Tata, Haier refrigeration, \\
\hline \multirow[t]{3}{*}{ Gambardella, McGahan } & Business model is a mechanism & Business model innovation in high technology areas that \\
\hline & for turning ideas into revenue at & permits small organizations to exploit their ideas. \\
\hline & reasonable cost & Examples: Ideo, Apple, Yogitech + biotech \\
\hline \multirow[t]{3}{*}{ Itami, Noshino } & ..business model is a profit & Puts learning centre stage, \\
\hline & model, a business delivery & classification by firm systems \\
\hline & system and a learning system & Examples: Toyota and Google \\
\hline Yunus, Moingeon, & A value system plus a value constellation & A social business model that is in between for profit and \\
\hline \multirow[t]{2}{*}{ Lehmann-Ortega } & & nonprofit. \\
\hline & & Examples: Veoila and Danone collaborations \\
\hline \multirow[t]{2}{*}{ Casadesus, Ricart } & The logic of the company, the way it works and how & Interfaces between business model, strategy and tactics \\
\hline & it generates value & Rynair \\
\hline \multirow[t]{2}{*}{ Demil, Lecoq } & The way resources are used to guarantee & Dynamics of business model \\
\hline & sustainability and development & change over time \\
\hline Rousselle, & Cross roads of skills and & Portfolios of business models \\
\hline Mangematin & customer needs & French biotech firms \\
\hline
\end{tabular}

Business models are not isolated by inference from any statistical research: instead we claim that business models are shaped by model work (Baden-Fuller, Morgan, 2010), that is, academics examine, with some significant depth of scientific research, specific examples that form our set of business model exemplar cases.

If we use the notion of 'model work', the fBComp is a business model that legitimates the firm social role in 
their context framework.

\section{Literature Review to Contextualize the fBComp in the Legitimacy Issue}

From a scientific perspective, in the last decades the change from the company that produces profit for shareholders to the company as an actor that contributes to the social community dynamics is increasingly marked by the social legitimacy principle and by CSR and ethic in business streams (Honeyman, 2014; Czinkota, Kaufmann and Basile, 2014).

From the legitimacy point of view, the notion was set by Parsons (1960) and then Weber (1978) as a state of congruence towards rules and social values. Academics of social theory and Resource-based View presented the concept of legitimacy (Suchman, 1995; Barney and Arikan, 2001; Johnson, Smith and Codling, 2006).

In the '70s, the neo-institutional theory, represented by Zucker (1977) and Meyer and Rowan (1977), while examining the ability of an organization to attain survival, stressed the significance of expressing behavioral patterns following several standards and beliefs of the reference context, in addition to more recognized factors such as organizational efficacy.

After Meyer and Rowan's work (1977), the neo-institutional school claims that companies that shape their behavior to ethical procedures and regulations of their context can be considered as legitimate.

The meaning of legitimacy employed in this study is succinctly expressed by the two academics Scott (1995) and Suchman (1995).

Scott (1995) says that legitimacy is not a commodity to be controlled but a condition reflecting cultural orientation, and consonance with appropriate rules.

Suchman (1995) shows that legitimacy is a universal perception or assumption for what the activities of an individual are desirable within some socially created system of norms.

The last description helps the authors to take a step forward the paper main objective: legitimacy is useful to reach the survival.

So, one could argue that the fBComp does not represent a new business approach, but rather a development towards the socialization/legitimacy of traditional business models.

According to reputation researches, the perception stakeholders mature as a consequence of corporate communication actions, refers to four areas (social, financial, product and employment) and is aimed to differentiate the company from its competitors (Gioia, Schultz, and Corley, 2000; Pruzan, 2001; Fombrun and Van Riel, 2003; Illia and Lurati, 2006; Van Riel and Fombrun, 2007).

However, according to the studies about legitimacy and reputation, fBComp conformity to contextual rules, norms and cultural values could support both the development of the fBComp in a competitive context and a cognitive legitimacy positioning (Abratt and Kleyn, 2012; Suchman, 1995).

This last consideration shows a dual corporate behavior approach towards the context of reference: economic and social (Czinkota, Kaufmann and Basile, 2014).

The first case considers when corporate behavior is geared towards economic results considering reputation as the capability to origin results related to competitiveness.

The social approach, conversely, caters to the role that the organization plays within its context, and, how the company itself is perceived by the community (Rindova, Williamson, Petkova and Sever, 2005).

The Italian Stability Law 2016 introduces the fBComp, by defining it as a society that follows profit and sustainability activities at the same time.

\section{Elements that Describes the Business Model Socializationfor the Value Co-Creation}

Regarding the social activities of the for profit companies, some academics define the company as a social (Kogut and Zander, 1996) or discursive (Tsoukas, 1996) community or a community of practice (Kreiner and Kristina, 1999).

Furthermore, Anderson, Aspenberg and Kjellberg, 2008; Araujo, Kjellberg and Spencer (2008) say that markets are co-created as players engaged in market and/or social actions (Storbacka and Nenonen, 2008).

Recurrent social practices enable the establishment of relationships between social actors and the co-creation of reciprocal condition to survive. Such relationships will evolve to adaptation of social actors' respective behaviors (Giddens, 1984; Staber and Sydow, 2002).

Berger and Luckmann (1966), besides, contended that organizations reflect their environment as they mirror socially gathered realities.

A continuous search by the organization for such a state of consonance (or structural coherence) between the establishment and/or preservation of its relationships with customers and other social actors, the mutual adaptation of practices and of behaviors employed by the social actors, expresses the existence of a constant process which influences the way a company survives under uncertainty (Barile, 2006; Golinelli, 2010). 
In such a dynamic business situation, the fBComp continually looks for social and economic actors with whom co-creating and preserving long-lasting relationships, through the development of consonance. This consonance is aimed to produce, co-produce and to contribute to the evolution of a civil society (Venturi and Rago, 2016; Golinelli, 2005).

The governance has to mark an approach based on "ethic" values to interact with a multi-agent context (Barile \& Gatti, 2003). Therefore, the context, that interacts with the company, is composed by consumers, competitors, supplier and numerous and heterogeneous actors, that are holders of numerous and heterogeneous values (Hawley, 1968; Tolbert and Zucker, 1996; Thornton, 2002; Hannan, Pólos and Carroll, 2007).

This social and economic interaction reflects a rational-cognitive-holder values firm that is consistent with norms and social practices, and mimics the context. This mimetic style is a phenomenon defined as isomorphism (Di Maggio and Powell, 1991; Di Maggio and Powell, 1983).

\section{Isomorphism as afBComp Aptitude}

Neo-institutionalist academics consider the company as a historical accretion of past practices and understandings acquire the moral and ontological status of taken-for-granted facts which, in turn, shape future relationships and cooperation (Zucker, 1977; Leblebici, Salancik, Copay and King, 1991; Barley and Tolbert, 1997).

The Stability Law 2016, art.1, comma 378, letter a) that sets the standard for fBComp follows this definition.

The law explains that the company, to be considered a benefit one, has to limit the negative effects ofits economic activities.

The isomorphism suggests that (Meyer and Rowan, 1977):

- meet the criteria set by the institutional context in order to be effective, to reach legitimacy and attain resources, and to survive;

- $\quad$ isomorphism is determined not only by the trend to adapt to the environment, but also by the action of the environment itself that leads to the construction of new companies consistent with rational myths (institutionalized rules, procedures, etc.);

- with every new myth that merges, new organizations have to meet the requirements that the myth has shaped.

These conditions of a rational behavior associated to normative and cultural needs of social context members, particularly individuals, gives to the organization a legitimacy, which support the construction of a promising reputation for the company and its members (Czinkota, Kaufmann and Basile, 2014).

The isomorphism phenomenon has several connotations depending on whether it evolves according to cognitive, normative and/or coercive circumstances (Leydesdorff, 2000).

Cognitive/mimetic isomorphism is described by a process of imitation/interpretation in which the relations between players are turned into cultural significance (Rao, 1994; Bridwell and Mezias, 2012).

In addition, the existence of rules leads to the identification of isomorphism based on:

1. Normative Isomorphism

2. Coercive Isomorphism (Golinelli, 2010)

Normative Isomorphism is established on company-context interactions.

Coercive Isomorphism is created on interactions between actors. In our paper the Statute adaptation could be an example of coercive isomorphism showing some governance values.

Finally, the legitimacy condition, the isomorphic phenomenon and the reputational behavior contribute to evolve the fBComp capability to survive, co-creating, in social and economic contexts (Deephouse and Carter, 2005; Sabeti, 2011).

\section{The State of Art of fBComp Law Application}

\subsection{Main features about law application}

What are the main influences that the for-benefit model applicability could have on the economy? Their potential impact depends on the organizational architecture and ecosystem of support (Sabeti, 2011). Starting from these considerations, a fBComp has two primary characteristics: a commitment to social purpose and a reliance on earned income. These two characteristics need to be taken into consideration by each socially minded entrepreneur.

They have to realize that cannot be inconsistent with their objectives. According to the social legitimation 
principle the form should follow the function. The knowledge of the structure that start up requires can maximize the potential of attaining financial, social purposes in the long term.

Combining social and financial purpose is not new: as instance, there are clinics, universities, etc. Nevertheless, the $\mathrm{fB}$ framework reaches a bigger scope. It rearranges governance, ownership, and stakeholder relationships in fundamentals ways.

The following characteristics are being codified in new legal structures and should be given priority on any for-benefit entrepreneurs' agenda:

Embedded scope: a commitment to mission is essential. Legitimacy is tied to scope.

Earned income: sales of goods/services produce incomes.

Stakeholder value: although for-profits give emphasis to shareholder value, for benefits pay more consideration to their influence on all stakeholders.

Capitalization: a key challenge that for-benefits meet is to create a structure that balances financial aims with the corporate mission and stakeholder obligations.

Ownership and governance: the director should share the commitment that stimulated the founder.

Performance measurement and reporting: the value proposition for a for-benefit entails a company capable of accounting for its total impact.

Finding a suitable ecosystem: when an entrepreneur starts a traditional business, accountants, stakeholders and consultants share an understanding of what that means and can offer resources that fit together. For-benefit companies have had to depend on these ecosystems but they can find resources that are more appropriate to their requirements.

In the past, an increasing number of trendsetters have been pushing against the limitations that distinct for-profits, nonprofits, and governments. Their actions go by different appellations: CSR, sustainability, citizenship, cause oriented marketing, morality, philanthropy.

If the for-benefit framework is accepted, all this novelty might establish a new sector.

\section{Research Design}

In order to conduct the research, the analysis of the fBComp is presented. The desk analysis was based on the development of a content analysis of the first Italian Report on fBComp.

Content analysis has been important in sociology, but equally applicable in the area of marketing, communications, management and organization studies (Merriam, 1998). Content analysis approach can be considered as an 'umbrella' that puts together several research techniques with a shared goal: to explore and answer to questions about a explicit subject. Furthermore, content analysis offers exact and comprehensive focus on phenomenon in its naturalistic and original background (Patton, 2002). The use of the content analysis, in this occasion, will investigate the issues of fBComp and its activities in depth as it allows the apply various methodologies at the same time (Malhotra and Birks, 2003).

The content analysis approach has been implemented as it proposes a chance for an empirical inquiry into fBComp as a current and relevant phenomenon within an exact real-life environment (Yin, 1994). A further benefit of utilizing content analysis is that it permits a deep understanding of the circumstances (Merriam, 1998), which enables the findings of the research to add a theoretical and practical contribution to the very few studies developed on the fBComp. Therefore, this study will evaluate the phenomenon, employing the chosen method and the sources of evidence to challenge the theoretical framework in question.

\subsection{Data Collection and Analysis}

As said before, the secondary data are collected analysing the first Italian Report on fBComp.

Quantitative data included information about the implementation of the strategy at the basis of the creation of fBComp.

The analysis of the collected data followed the process of combining the words into several categories of information and highlighting the differences and/or similarities of information found during the analysing of the first Italian Report on fBComp. Then, data were explored in line with suggestions from Patton (2002) applying preliminary a priori codes developed from the literature review presented before. In addition, researchers were paying attention to the possible emergence of new themes/codes. The original codes were afterward reorganized, in order to classify higher level categories that allow bonds across the empirical data and the recurrent topics in 
literature review. Alternative justification of the coding and findings were presented by researchers (Patton, 2002), for example, this involved the possibility to emphasize the analysis of the fBComp objectives. The researchers, in fact, took into account the more individualistic goals that pushed the chosen firms to becoming fBComp: surviving the economic crisis helping the communities.

The data were explored using the corporate reports made accessible by the organizations about their corporate strategy and its results in terms of ethics, corporate social responsibility, non for profit performances and sustainability. Relying on content analysis method, the data sets were triangulated (Greene and Caracelli, 1997), trying to find supporting elements on corporate websites and other sources of information. This helped to boost the reliability and confidence in the original justification attained.

Other matters related to bias, generalization of achieved results and convincingness were determined thanks to triangulation in order to contrast and/or authenticate the data collected from specific sources (Greene et al., 1989). Besides, triangulation was applied in order to produce a dialectic of learning. This mixed approach aided us to be able to reach several points of view upon the other arguments under scrutiny. The consequential dialectic of learning raised from the gap between what appeared to be patently obvious in the data collected, what seemed to be commonly right in the corporate reports of fBComp and what discrepancies are found when evaluating all those issues with other considerations of the same data (Greene and Caracelli, 1997).

Thanks to this particular analysis, there were numerous key aspects of fBComp that were highlighted. In the next section, the findings are proposed with background information and discussions.

\section{Findings and Discussion}

Since 1 January, 2016 Italy is one of the country in the world (after US and UK) that has introduced the fBCompanies (1. 28 December 2015, n. 208 Art.1, from par. 376 to 384, 2016 called Stability Law). These are firms that in addition to the ordinary institutional aim (profit or mutual) purpose common benefit acting responsibly, sustainable and transparent to people, communities, place and the environment, property and cultural social activities, organization and association and other stakeholders. Both existing companies and those of new constitution may include in their statutes specific clauses which provide the purposes of common benefit.

According to the First Italian fBCompReport (Societax, October, 2017), we highlight the most relevant figures and features of the 115 companies registered in Italy to date. Figures in the first report show than more than $50 \%$ of firms (23) are new (see table 2). Over a quarter (21) of these are old companies which have decided to revise their statutes including the clauses of the new law.

In the first years, considering the content analysis results, most of the fBComp have chosen the capitalist type of society. Ltd is used almost in every case. Within the Ltd there are variants of the innovative start-up and agriculture firm. Moreover, it's being recorded the first cooperative fBComp in Italy and in the world, as in US is not provided.

The fBComp name is not required by the law which mentions that expression as an option for the companies that have adopted the new statute. In this mean, the $\mathrm{fB}$ can be viewed as a brand for reputational advantage. Almost all analysed firms that have issued the statutory requirement of social benefit named the expression "benefit society". At the end, there is only one company (it is a $\mathrm{SpA}$ ) who omitted in its name the fB abbreviation.

According to our data, the phenomenon of the fBComp is particularly widespread in the North of Italy. This is probably due to the fact that it's the part of the country with the largest numbers of companies. As summarized in the explored reports, the fBComps have normally a narrow company structure, often the owner drives the governance.

The most interesting information - gathered from the data - is related to the way companies have defined their social purpose.

Thanks to the statutes analysis, we have identified the following fBComp categories (see table 3).

1. Generic fBComp (97 companies)

2. Specific fBComp (18 companies)

The second category shows that there are some fBComps that clearly claims their social purpose. For example, there is Anima e corpo Srl Società Benefit. This company operates in the field of events organization, and it is committed to help the development of youth belonging to the Salesian community and to support the Salesian equipment management situated in Lecce town; Events Srl SB will allocate a part of the profits to the non-profit "solidarity farm" (partly already operating in a land of about 40 hectares, 10 of which are the result of a donation, and 30 of a free loan, where there is a cottage of about 150 meters, a stable and a barn, and where they graze 10 horses, three donkeys, 20 cows, 50 sheep and 10 goats), situated in Alia village (Palermo), composed of 50 sqm 
prefabricated wooden buildings units, totally furnished (i.e. complete with furniture and furnishings), to be realized and assigned, on loan for free use, to homeless people, those who live on the street and under bridges and to families who are in a serious state of poverty or in precarious economic conditions.

Table 2. Information about Italian fBComp

\begin{tabular}{lllll}
\hline \multicolumn{1}{c}{ Type of society } & fBComp sign & Location & Company structure & Industry \\
\hline 36 Ltd (srl) & $99 \%$ included & 27 North Italy & 6 one owner & 6 grocery \\
3 Ltd (srl) innovative start up & S.p.A omitted & 10 Centre & 35 from 2 to 5 shareholders & 4 energy \\
3 Ltd (srl) simplified & & 7 South Italy & 2 from 6 to 10 shareholders & 2 agriculture \\
2 Ltd (srl) agriculture & & 1 more than 21 shareholder & 2 finance and insurance \\
2 Corporation (Spa) & & & 2 real estate \\
1 Cooperative company & & & 3 educational \\
& & & 2 tourism \\
\end{tabular}

Source: our elaboration.

Table 3. Classification of Italian fBComp

\begin{tabular}{|c|c|c|}
\hline & Name of the company & $\begin{array}{l}\text { Generic (G)/ } \\
\text { Specific (S) }\end{array}$ \\
\hline 1. & $403030 \mathrm{SB}$ Srl SB & G \\
\hline 2. & Agromed Srl SB & G \\
\hline 3. & Aleoop Srl SB & G \\
\hline 4. & Alma Cordis Srl SB & G \\
\hline 5. & Antica Erboristeria SpA SB e B Corp ${ }^{\circledR}$ & G \\
\hline 6. & Anima e corpo Srl Società Benefit & $\mathrm{S}$ \\
\hline 7. & Arca Srl SB & S \\
\hline 8. & Artes Srl SB & G \\
\hline 9. & Assicons Srl SB & S \\
\hline 10. & BE Srl Società Benefit & $\mathrm{S}$ \\
\hline 11. & BMP Srl Società Benefit & $\mathrm{S}$ \\
\hline 12. & Boboto Srl Società Benefit e Pending B Corp & G \\
\hline 13. & Cantiere Verde Società Agricola Srls SB & G \\
\hline 14. & Centriservire la famiglia Srl Società Benefit & G \\
\hline 15. & Centro di studio e di psicoterapia della persona-società benefit S.s.t.p. & G \\
\hline 16. & Ciboprossimo.net Srl SB & G \\
\hline 17. & Cisnusculum Srl SB & G \\
\hline 18. & ConfiniAzzurri Srl SB & G \\
\hline 19. & Croqqer Srl SB e B Corp ${ }^{\circledR}$ & G \\
\hline 20. & D-Orbit Srl e B Corp ${ }^{\circledR}$ & $\mathrm{S}$ \\
\hline 21. & Dermophisiologique Srl SB e B Corp ${ }^{\circledR}$ & G \\
\hline 22. & Dialisi Sant' Angelo Srl Società Benefit & G \\
\hline 23. & Edilgeo 4.0 SB a Responsabilità limitata & $\mathrm{S}$ \\
\hline 24. & Elidria Srl SB e B Corp ${ }^{\circledR}$ & G \\
\hline 25. & Esdebitami Srl Società Benefit & G \\
\hline 26. & Eso Srl SB & G \\
\hline 27. & Estia Soc. Cooperativa Benefit a RL & G \\
\hline 28. & Events Srl SB & S \\
\hline 29. & Executive service Srl SB e B Corp ${ }^{\circledR}$ & G \\
\hline 30. & Ex Terra Srl SB (exterra.srl) & G \\
\hline 31. & Ethic jobs Società Benefit Srl (ethicjobs.com) & $\mathrm{G}$ \\
\hline
\end{tabular}


32. Eywa Hard Fun Srls SB $\quad$ G

33. European learning community S.n.c. Società Benefit di Carolina Eugenia Lopasso e Susana Alicia G Grimaldi

34. Fameroll Srl SB

35. Firstfloor Srl - Yoroom Srl SB e Pending B Corp ${ }^{\circledR}$

36. Funky tomato Società agricola Srl SB (www.funkytomato.it)

37. Friends Srl SB

38. Farmitalia Research SB

39. Fit Srl Società Benefit

40. Greenapes Srl SB e B Corp ${ }^{\circledR}$ (www.greenapes.com)

41. Green Capital Alliance Società Benefit Srl (www.greencapitalalliance.com)

42. Green Idea Technologies Srl SB (www.greenideatech.com)

43. Green Metal Srl SB

44. Grup Srl Società Benefit

45. ICS Maugeri SpA SB (www.fsm.it)

46. Il Faro Società Benefit

47. Immagina Srl Società Benefit

48. Immobil cartiera Srl Società Benefit

49. Insieme Soc. Cooperativa Benefit e B Corp ${ }^{\circledR}$

50. La nuova colonia SpA (www.Lanuovacoloniaspa.com)

51. Lightson Srl Società Benefit

52. Little Genius International Srl SB e B Corp ${ }^{\circledR}$ (www.littlegenius.it)

53. Madre di Dio Srl Società Benefit

54. Mail work Ecosostenibili Srl SB e B Corp ${ }^{\circledR}$ (www.tweegs.com)

55. Marioway Srl SB e B Corp ${ }^{\circledR}$ (www.marioway.it)

56. MastIcc SB Srl

57. MefirSrl SB

58. MeritsSrl SB

59. Millenotti e più Srl Società Benefit

60. Mondora Srl SB e B Corp ${ }^{\circledR}$ (www.mondora.com)

61. Mozart Srl Società Benefit

62. Nativa Srl Società Benefit e B Corp ${ }^{\circledR}$ (wwww.nativalab.com) $\quad$ G

63. Nature Talkers Società Benefit Srl

64. Nested Srl Società Benefit

65. NWG Energia Srl SB e B Corp ${ }^{\circledR}$ (www.nwgenergia.it)

66. Onebarter Srl SB

67. Open innovation Srl SB

68. Ottocento Napoletano Srl SB

69. Paradisi Srl e B Corp ${ }^{\circledR}$ (www.paradisi.it)

70. Pasticceria Filippi Srl SB e B Corp ${ }^{\circledR}$ (www.pasticceriafilippi.it)

71. Pieces of Venice S.r.1. - Società Benefit

72. Positive Impact Srl SB Pending e B Corp

73. Radici Srl SB

74. Reynaldi Srl Società Benefit (www.reynaldi.it)

75. Rigenera innovation SB Srl

76. Rpxpartners Srls SB

77. Santa Francesca Cabrini Srl SB (www.santafrancescacabrini.com)

78. Società Benefit AMD Srl SB

79. Soc. Cooperativa Stella Polare SB

80. Sagelio Srl SB

81. She Square Società Benefit Srl e Pending $B$ Corp ${ }^{\circledR}$

82. Sind Neurottimo Srl Società Benefit

83. Slow Food Promozione Srl (www.slowfood.it)

84. Spazio Noprofit Srl Società Benefit

85. S.W.P. Sustainable Water Projects Srl Società Benefit

86. Top in town Srl SB 


\begin{tabular}{lll}
\hline 87. & Texture S.r.l. Società Benefit & $\mathrm{G}$ \\
88. & Terre alte del Piceno Srl Società Benefit & $\mathrm{G}$ \\
89. & TreiSrl SB & $\mathrm{G}$ \\
90. & Trecuori SpA Società Benefit & $\mathrm{G}$ \\
91. & Turismo sostenibile Srl SB & $\mathrm{G}$ \\
92. & United4Business Srl SB & $\mathrm{G}$ \\
93. & Valli del Bitto Società Benefit e B Corp® (www.formaggiobitto.com/it/) & $\mathrm{G}$ \\
94. $\quad$ Veganok Srl Società Benefit (www.veganok.com/it) & $\mathrm{G}$ \\
95. Villamare Srl SB & $\mathrm{G}$ \\
96. $\quad$ Vision Società Benefit & $\mathrm{G}$ \\
97. $\quad$ Wami Srl SB (www.wa-mi.org/) & $\mathrm{G}$ \\
98. Way2global Srl SB & $\mathrm{S}$ \\
99. Welumen Srl Società Benefit (www.welumen.com) & $\mathrm{G}$ \\
100. Wise Srl Società Benefit & $\mathrm{G}$ \\
101. Whatmatters Società Benefit Srl & $\mathrm{G}$ \\
102. Worth Wearing Srl SB (www.worthwearing.org) & $\mathrm{G}$ \\
103. Yumax Società Cooperativa SB & $\mathrm{G}$ \\
104. Xexagro Urban Farming Srl Società Benefit (www.hexagrourbanfarming.com) & $\mathrm{G}$ \\
105. Zordan Srl SB e B Corp® (www.zordan1965.it) & $\mathrm{G}$ \\
\hline
\end{tabular}

Source: our elaboration.

The analysis highlighted that there are several advantages for the Benefit Corporation.

The information collected in the reports show that benefit corporation has benefits that make to be a fBComp a very attractive perspective.

First of all, as its name points, it proposes 'sustainable' businesses a chance to pay attention to all kind of stakeholders, not only to shareholders. In fact, these firms states in their reports that they really want to attain a "general public benefit".

Furthermore, they can reach their goal of pursuing "specific public benefits," including, enhancing their involvement in terms of arts and sciences, human resources health, or economic/financial advantages.

In addition, fBComp directors have to take into account various stakeholders' needs when choosing the company's "best interests." Therefore, the new 'sustainable' form allows entrepreneurs to reach both profits and socially beneficial aims, to follow the interests of both shareholders and stakeholders at the same time.

Moreover, according to the analysis of the reports, the fBComp law helps companies to select a real social mission. It does so in different ways: for example, the laws ask the fBComp to public an annual benefit report; to show its specific beneficial goals, etc. In the report, the benefit corporation have to embrace a review of its social and environmental concert arranged following a third party standard. These reports are able to offer to stakeholders information on the corporation's actual observance of its social aims. It is important to say that unlike other statutes, the new laws grant all publics the right to state a claim against companies for failure to reach the corporation's general/specific social scope.

This measure allows the fBComp another advantage: a strong brand. More stakeholders are using nonfinancial information to choose and then buy a product/service. Social companies seem to benefit from this new interesting trend. In fact, the fBComp are able to differentiate themselves from the 'greenwashers', i.e. the companies that seek market economic benefits by miscommunicating their environmental/social efforts.

The content analysis, thus, makes very clear that the fBComp allows firms a number of relevant advantages in pursuing social enterprise but on the same time, it also carries severe requirements, not mere chances, for CEOs to consider stakeholder needs.

The content analysis, in fact, highlighted that there are also disadvantages of being a Benefit Corporation.

The fBComp has acquired strong support from policymakers, but this also means that pursuing an additional social duties, the company can be limited in reaching its profit. Since, nevertheless, this business form exists in part to endorse a social cause rather than just to make revenues, this cannot be judged as a disadvantage. Any stakeholders who endorse the fBComps, support the additional responsibilities and its limits. 


\section{Conclusions and Further Research}

The major contributions of this study are as follows: firstly, this is the first study that identifies and examines fBComp in Italy considering this form as part of the strategic business approaches applied in the Italian context. Prior research has focused exclusively on UK and US companies.

In addition, the findings from this study highlight the root causes and effects of being a fBComp. Second, this research study demonstrated the importance played by this form for Italian firms.

Finally, this study explores a more strategic role for sustainability: sustainability can help brands successfully communicate to customers and to all kind of stakeholders.

Starting from these considerations, there are many relevant considerations emerging from this state-of-the-art.

This study states that the fBComp is a social co-creator, in interaction with other social and economic actors, within their manufacturing capabilities.

Such scenario shows advancement from the traditional business model to a social business model, in which the entrepreneur's legitimacy and reputational behaviors aren't separated. On the basis of this approach, the fBComp is a system aware to be an ethic, social and economic actor, part of a suvrasystem composed by numerous and heterogeneous components.

Whether the fBComp will definitely modify the face of business and the relationship between it, the people and whole society, and whether firms will successfully endorse corporate social responsibility, is yet to be seen.

Nevertheless, the new law has finally succeeded in pushing companies to fully consider all kind of stakeholder interests. The combination of financial profit and social/environmental responsibility within the fBComp asset links it with CSR, sustainability and business ethics theories, and future study will deeply analyse these particular bonds.

In fact, though, this study only performs an empirical analysis on a small number of companies. Future studies should overcome this limit, by using larger samples.

Despite this limit, the study suggests some interesting future research questions, as instance as:

1. Considering that the ethic is a subjective value, is it necessary to create a fBComp to show the governance's ethic value?

2. How do we measure the social effects?

3. Have a fBComp more probabilities to survive in a sustainable way?

4. Can the statute modification, introduced by Italian Stability Law, represent the governance and/or the owners' social values about social legitimacy? In case of a positive answer, can those entrepreneurs, who do not use or modify the statute, be considered as interested about social behavior only to win the competition against their competitors?

5. In our time, in which economic neoliberal approaches and deterministic traditional business models made their come back, will researchers and practitioners consider the fBComp only a brand to better compete or rather a starting point that could lead to the definition of a new social business model?

Answering to these questions will provide a laboratory to analyse the interplay between assessment, CSR communication, transparency, ethics and process, with socially responsible and sustainable corporate purpose.

\section{References}

Abratt, R., \& Kleyn, N. (2012). Corporate Identity, Corporate Branding and Corporate Reputations: Reconciliation and Integration. European Journal of Marketing, 46(7/8), 347-356. http://dx.doi.org/10.1108/03090561211230197

Anderson, P., Aspenberg, K., \& Kjellberg, H. (2008). The configuration of actors in market practice.Marketing Theory, 8(1), 67-80.

Araujo, L., Kjellberg, H., \& Spencer, R. (2008). Market practices and forms: introduction to special issue.Marketing Theory, 8(1), 5-14. http://dx.doi.org/10.1177/1470593107086481

Barile, S. (2006).L'Impresa come Sistema. Contributi sull'Approccio Sistemico Vitale (ASV). Giappichelli Editore, Torin.

Barile, S., \& Gatti, M. (2003). Riflessioni sull'etica dell'impresa secondo l'approccio sistemico. Esperienze d'Impresa, Serie Speciale, S/1, 235-244. 
Barney, J. B., \& Arikan, A. M. (2001).The resource-based view: Origins and implications. Blackwell Business: Oxford.

Berger, P., \& Luckmann, T. (1966).The Social Construction of Reality. New York, Doubleday.

Brammer, S., Jackson, G., \& Matten, D. (2012). Corporate social responsibility and institutional theory: New perspectives on private governance. Socio-economic Review, 10(1), 3-28. http://dx.doi.org/10.1093/ser/mwr030

Bridwell, E. N., \& Mezias, M. S. J. (2012). The Quest for Cognitive Legitimacy: Organizational Identity Crafting and Internal Stakeholder Support. Journal of Change Management, 1-19

Czinkota, M., Kaufmann, H.R., \& Basile, G. (2014).The relationship between legitimacy, reputation, sustainability and branding for companies and their supply chains. Industrial Marketing Management, 43, pp. 91-101. http://dx.doi.org/10.1016/j.indmarman.2013.10.005

Deephouse, D.L., \& Carter, S.M., (2005), “An examination of differences between organizational legitimacy and organizational reputation. Journal of Management Studies, 42(2), 329-360.

Di Maggio P., \& Powell, W. W. (1983). The iron cage revisited: Institutional isomorphism and collective rationality in organizational field. American Sociological Review, 48.

Di Maggio, P., \& Powell, W. W. (1991). The New Institutionalism in Organizational Analysis(Vol. 17 No. 3 ). University of Chicago Press.

Fombrun, C. J., \& Van Riel, C. B. M. (2003). Fame\& Fortune: How Successful Companies Build Winning Reputation. Prentice Hall, Financial Times, Upper Saddle River.

Greene, J.C., \& Caracelli, V.J. (1997). Advances in Mixed-Method Evaluation: The Challenges and Benefits of Integrating Diverse Paradigms. Jossey-Bass Publishers, San Francisco, CA.

Greene, J. C., Caracelli, V. J., \& Graham, W. F. (1989). Towards a conceptual framework for mixed method evaluation designs. Educational Evaluation and Policy Analysis, 11(3), 255-274. http://dx.doi.org/10.3102/01623737011003255

Giddens, A. (1984). The Costitution of Society: Outline of the Theory of Structuration.Berkeley, CA: University of California Press.

Gioia, D. A., Schultz, M., Corley, K. G. (2000). Organizational identity, image, and adaptive instability.Academy of Management Review, 25(1), 63-81. http://dx.doi.org/10.2307/259263

Golinelli, G.M. (2010). L'approccio sistemico al governo dell'impresa. Verso la scientificazione dell'azione di governo, vol. II, Cedam, Padova.

Golinelli, M. G. (2005). Recenti sviluppi nelle relazioni tra economia e finanza del governo dell'impresa: spunti di riflessione, Sinergie, 67, 19-20.

Hannan, M. T., Polos, L., \& Carroll, G. R. (2007). Logics of Organization Theory: Audiences, Codes, and Ecologies.Princeton University Press, Princeton, NJ.

Hasler, J. E. (2014). Contracting for Good: How Benefit Corporations Empower Investors and Redefine Shareholder Value. Virginia Law Review, 1279-1322.

Hawley, A. H. (1968). Human Ecology. In David L. Sills (Ed.), International Encyclopedia of the Social Sciences.New York: McMillan.

Hiller, J. (2013). The benefit corporation and corporate social responsibility. Journal of Business Ethics, 118(2), 287-301. http://dx.doi.org/10.1007/s10551-012-1580-3

Honeyman, R. (2014).The B Corp Handbook: How to Use Business as a Force for Good. Berrett and Koehler Publishers Inc., San Francisco.

Illia, L., \& Lurati, F. (2006).Stakeholder perspectives on organizational identity: Searching for a relationship approach. Corporate Reputation Review, 8(4), 293-304. http://dx.doi.org/10.1057/palgrave.crr.1540256

Johnson, G., Smith, S., \& Codling, B. (2006). Microprocesses of institutional change in the context of privatization.Academy of Management Review, 25(3), 572-580. http://dx.doi.org/10.2307/259310

Kogut, B., \& Zander, U. (1996).What do firms do? Coordination.identity and learning, Organization Science, 7 , 502-518.

Kreiner, K., \& Kristina, L. (1999). Knowledge assimilation: Mobilizing distributed knowledge. Paper presented 
at the Third World Congress on the Management of Intellectual Capital, Hamilton, Ontario, Canada, January 20.

Leblebici, H., Salancik, G., Copay, A., \& King, T. (1991). Institutional change and the transformation of the U.S. broadcasting industry.Administrative Science Quarterly, 36, 333-363.

Leydesdorff, L. (2000). Luhmann, Habermas and the Theory of Communication.Systems Research and Behavioral Science, $17(3)$, 273-288. http://dx.doi.org/10.1002/(SICI)1099-1743(200005/06)17:3\%3C273::AID-SRES329\%3E3.0.CO;2-R

Loewenstein, M. J. (2013). Benefit corporations: A challenge in corporate governance. The Business Lawyer, 1007-1038.

Malhotra, N. K., \& Birks, D. F. (2003). Marketing Research: An Applied Approach (2nd ed.). Pearson Education Limited, Essex.

Merriam, S. B. (1998), Qualitative Research and Case Study Applications in Education. Jossey-Bass, San Francisco, CA.

Meyer, J. W., \& Rowan, B. (1977). Istitutionalized Organitations: Formal Structure as Myth and ceremony.American Journal of Sociology,83(2), 340-363.

Murray, J. H. (2012). Choose Your Own Master: Social Enterprise, Certifications and Benefit Corporation Statutes. American University Business Law Review. Retrieved from https://ssrn.com/abstract=2085000

Parsons, T. (1960). Structure and Process in Modern Societies. New York: John Wiley.

Patton, M. Q. (2002). Qualitative Research and Evaluation Methods. Sage Publications, Thousand Oaks.

Porter, M. E., \& Kramer, M. R. (2011). Creating shared value. Harvard Business Review.

Pruzan, P. (2001). Corporate reputation: Image and identity. Corporate Reputation Review, 4(1), 50-64.

Rao, H. (1994). The Social Construction of Reputation: Certification Contests, Legitimation, and the Survival of Organizations in the American Automobile Industry: 1985-1912. Strategic Management Journal, 29-44.

Rawhouser, H., Cummings, M., \&Crane, A. (2015). Benefit corporation legislation and the emergence of a social hybrid category", California Management Review, 57(3), 13-35.

Rindova, V. P., Williamson, I. O., Petkova, A. P., \& Sever, J. M.(2005). Being Good or Being Known: An Empirical Examination of the Dimensions, Antecedents, and Consequences of Organizational Reputation. Academy of Management Journal, 48(6), 1033-1049.

Sabeti, H. (2011). The for-benefit enterprise. Harvard Business Review, 89, 99-104.

Scott, W.R. (1995). Institutions and Organizations. Thousands Oaks, CA: Sage.

Staber, U., \& Sydow, J., (2002). Organizational Adaptive Capacity A Structuration Perspective.Journal of Management Inquiry, 11(4), 408-424

Storbacka, K., \& Nenonen, S. (2008). Scripting markets: From value propositions to market propositions. Otago Forum 2, Academic papers, 12, 187-212. http://dx.doi.org/10.1016/j.indmarman.2010.06.038

Stubbs, W. (2014). Exploration of an emerging sustainable business model: the B Corp model.Proceedings of the 25th Annual Conference of the International Association for Business and Society (pp. 280-291). Sydney: IABS.

Suchman, M. C. (1995). Managing Legitimacy: Strategic and Institutional Approaches", Academy of Management Review, 20(3), 571-610.

Thornton, P. H. (2002). The rise of the corporation in a craft industry: Conflict and conformity in institutional logics.Academy of Management Journal, 45, pp. 82-101

Tolbert, P. S., \& Zucker, L. G. (1996). Institutionalization of Institutional Theory. In Clegg S. R. and Hardy C. and Nord W. R. (Eds.), Handbook of Organization Studies. Sage, London

Tsoukas, H. (1996). The firm as a distributed knowledge system: a constructionist approach.Strategic Management Journal, 17, 11-25. http://dx.doi.org/10.1002/smj.4250171104

Van Riel, C. B. M., \& Fombrun, C. J. (2007).Essentials of Corporate Communication. Routledge, New York.

Venturi, P., \& Rago, S. (2016). Benefit corporation e impresa sociale: convergenza e distinzione. Impresa Sociale. Retrieved from http://www.rivistaimpresasociale.it/rivista/item/135-benefit-corporation.html 
Weber, M., (1978). Economy and Society. University of California Press.

Yin, R. K. (1994). Case Study Research - Design and Methods, Applied Social Research Methods Series 5 (2nd ed.). Sage, Newbury Park, CA.

Zucker, L. G. (1977). The role of institutionalization in cultural persistence. Sociology of Organization, 2, 1-47. http://dx.doi.org/10.2307/2094862

\section{Copyrights}

Copyright for this article is retained by the author(s), with first publication rights granted to the journal.

This is an open-access article distributed under the terms and conditions of the Creative Commons Attribution license (http://creativecommons.org/licenses/by/4.0/). 